\title{
Pelaksanaan Pendekatan Scientific Dalam Pembelajaran Tematik
}

\author{
Yuris Indria Persada ${ }^{1}$, Ery Tri Djatmika ${ }^{2}$, I Nyoman Sudana Degeng ${ }^{3}$ \\ ${ }^{1}$ Pendidikan Dasar-Universitas Negeri Malang \\ ${ }^{2}$ Manajemen-Universitas Negeri Malang \\ ${ }^{3}$ Teknologi Pembelajaran-Universitas Negeri Malang
}

\begin{tabular}{l} 
INFO ARTIKEL \\
\hline Riwayat Artikel: \\
Diterima: $12-07-2019$ \\
Disetujui: $24-01-2020$ \\
\hline
\end{tabular}

\section{Kata kunci:}

scientific approach; thematic learning; 2013 curriculum; pendekatan scientific; pembelajaran tematik; kurikulum 2013

\begin{abstract}
This study aims to give information related to the implementation of scientific approach in thematic instruction integrated to Curriculum 2013 at Elementary School stage. Several aspects in the implementation of scientific approach are as follows: (1) planning the scientific lesson, (2) teaching and learning process, (3) evaluating, and (4) valuing the lesson using scientific approach in thematic instruction. This is a qualitative method research using case study approach. The data analysis used several instruments such as data reduction, data presentation, and verification. The result of this study showed that the implementation of scientific approach met several obstacles.

Abstrak: Penulisan ini bertujuan untuk memberikan informasi tentang penerapan pendekatan scientific dalam pembelajaran tematik terpadu pada kurikulum 2013 di Sekolah Dasar. Pelaksanaan pendekatan scientific, yakni pada aspek-aspek (1) perencanaan pembelajaran scientific, (2) proses pembelajaran, (3) evaluasi, dan (4) kebermaknaan pembelajaran dengan pendekatan scientific dalam pembelajaran tematik. Penelitian ini menggunakan metode penelitian kualitatif dengan jenis penelitian studi kasus. Data hasil penelitian ini diolah dengan reduksi data, penyajian data, dan verifikasi. Hasil penelitian menunjukkan bahwa pelaksanaan pembelajaran scientific terdapat beberapa kendala.
\end{abstract}

ABSTRAK

\author{
Alamat Korespondensi: \\ Yuris Indria Persada \\ Pendidikan Dasar \\ Universitas Negeri Malang \\ Jalan Semarang 5 Malang \\ E-mail: yurispersada@gmail.com
}

Dunia pendidikan menjadi perhatian khusus pemerintah. Banyak hal yang dilakukan pemerintah untuk menghasilkan SDM berkualitas. Salah satu langkah tersebut yakni melakukan penyempurnaan terhadap kurikulum yang sesuai dengan perkembangan zaman. Kurikulum Tingkat Satuan Pembelajaran (KTSP) disempurnakan menjadi kurikulum 2013. Kurikulum menempati posisi penting dalam mencapai tujuan pendidikan. Perubahan Kurikulum Tingkat Satuan Pendidikan (KTSP) menuju kurikulum 2013 terjadi beberapa perubahan mendasar dalam proses belajar mengajar di dalam kelas. Pelaksanaan pembelajaran tematik pada kurikulum KTSP hanya dilakukan di kelas rendah, tetapi pada kurikulum 2013 pelaksanaan pembelajaran telah menggunakan pembelajaran tematik terpadu untuk semua jenjang kelas. Menurut (Mukhlis, 2012) merupakan proses pembelajaran menggunakan model terpadu, hal ini tentunya dapat menumbuhkan motivasi peserta didik untuk ikut serta dalam belajar, aktif terlibat dan mampu memecahkan masalah sesuai fakta atau fenomena yang ditemui serta dapat meningkatkan kreativitas tinggi. Acuan pembelajaran tematik pada Fogarty (1991) yaitu "the integrated model blends the four major disciplines by setting curricular priorities in each and finding the overlapping skills, concepts, and attitudes...".

Perubahan pada empat elemen kurikulum, yakni perubahan pada SKL, Standar Isi, Standar Proses dan Standar Penilaian. SKL pada Kurikulum 2006 (KTSP) diturunkan dari Standar Isi, sedangkan pada Kurikulum 2013 SKL diturunkan dari kebutuhan yang meliputi SKL Sikap, SKL Pengetahuan, dan SKL Keterampilan. Perubahan Standar Isi pada Kurikulum 2013 meliputi pengurangan mata pelajaran disertai penyesuaian materi dengan perkembangan ilmu pengetahuan dan teknologi serta adanya penambahan jam pelajaran. Sedangkan perubahan Standar Proses pada Kurikulum 2013 adalah penggunaan Pendekatan Scientific, meliputi kegiatan mengamati, menanya, mengumpulkan informasi, menalar, dan mengomunikasikan dalam kegiatan pembelajaran. Pendekatan scientific dalam hal keilmiahannya sangat tepat untuk diimplementasikan guna peningkatan kualitas peserta didik dalam ranah pengetahuan maupun keterampilan (Raharjo, 2014). Adapun perubahan Standar Penilaian yaitu pada Kurikulum 2013 lebih menekankan pada Penilaian Autentik yang meliputi penilaian sikap, pengetahuan, dan keterampilan. 
Perubahan standar proses pada kurikulum 2013 yakni penggunaan pendekatan scientific dalam proses pembelajaran di dalam kelas. Pembelajaran scientific pada dasarnya merupakan serangkaian proses pembelajaran yang memungkinkan peserta didik untuk aktif mengkonstruk pengetahuannya baik secara konsep, hukum maupun prinsip melalui tahapan-tahapan mengamati, menanya, mencoba/mengumpulkan informasi, mengasosiasi/menalar dan mengomunikasikan pengetahuan yang mereka temukan. Penggunaan pendekatan ini diharapkan guru tidak hanya mampu menyampaikan materi pelajaran dengan baik, serta mampu memahami karakteristik peserta didik (rasa ingin tahu) agar tujuan pembelajaran dapat tercapai. Pendekatan ini berbeda dari pendekatan pembelajaran kurikulum sebelumnya (KTSP). Hal ini karena pendekatan scientific diharapkan mampu membekali rasa tanggung jawab yang tinggi pada generasi mendatang (Junaidi \& Aprison, 2017). Pada setiap langkah inti proses pembelajaran, guru akan melakukan langkah-langkah pembelajaran sesuai dengan pendekatan ilmiah (pendekatan Scientific).

Kurikulum 2013 ini diterapkan di sekolah dasar baik di wilayah perkotaan maupun di pedesaan. Penerapan di lapangan tentunya masih mengalami permasalahan. Hal ini terlihat dalam langkah-langkah pembelajaran yang ditulis dalam RPP terkesan bahwa unsur-unsur Scientific (mengamati, menanya, mengumpulkan informasi, menalar dan mengomunikasikan) sebagai langkah pembelajaran yang harus selalu berurutan dalam penerapannya sehingga kegiatan pembelajaran menjadi kaku, sesungguhnya unsur-unsur pendekatan Scientific tersebut tidak harus selalu berurutan dalam penerapannya.

Proses pembelajaran dalam kurikulum 2013 dengan menggunakan Pendekatan Scientific tidak semata-mata mudah untuk diterapkan oleh para guru. Beberapa kendala dalam penerapan pendekatan Scientific didalam pembelajaran meliputi: (1) dalam prosesnya, peserta didik seringkali acuh tak acuh terhadap fenomena alam, (2) motivasi peserta didik rendah, (3) memerlukan waktu persiapan yang lama dan matang, (4) biaya dan tenaga relatif banyak, (5) jika tidak terkendali akan mengaburkan makna serta tujuan pembelajaran. Semakin banyak kendala maupun dampak dari perubahan kurikulum ini, semakin banyak informasi yang harus diselami lebih dalam. Oleh karena itu, penelitian ini dilakukan untuk melihat lebih dalam pelaksanaan pendekatan scientific, yakni pada aspek-aspek: (1) perencanaan pembelajaran scientific, (2) proses pembelajaran pendekatan scientific, (3) evaluasi pembelajaran pendekatan scientific, dan (4) kebermaknaan pembelajaran dengan pendekatan scientific dalam pembelajaran tematik

\section{METODE}

Penelitaian ini menggunakan pendekatan kualitatif dengan jenis yang dilaksanakan yaitu studi kasus. Kejadian yang diteliti dan diobservasi tentang implementasi pendekatan scientific dideskripsikan secara mendalam. Prosedur penelitian menghasilkan data deskriptif dari orang dan perilaku yang diamati di dalam kelas. Kegiatan perencanaan, pelaksanaan, penilaian, hambatan dan upaya yang dilakukan oleh guru untuk mengatasi hambatan dalam pelaksanaan pendekatan scientific dikumpulkan yang kemudian disajikan dalam bentuk kata-kata.

Penelitian ini dilaksanakan di Kelas IVA SDN Percobaan 1 Kota Malang. Kelas yang dijadikan objek penelitian yaitu kelas IVA dengan jumlah siswa 29. Kelas yang diambil peneliti merupakan kelas tinggi dengan pertimbangan lebih mudah dalam pengamatan dan pengondisian siswa. Teknik yang digunakan dalam pengumpulan data penelitian ini, yaitu (1) teknik observasi, (2) teknik wawancara, (3) teknik dokumentasi. Aspek yang diobservasi oleh peneliti yakni perencanaan hingga penerapan pendekatan scientific dalam pembelajaran tematik terpadu selama proses pembelajaran. Hasil dari observasi kemudian dicatat secara subjektif oleh peneliti. Jenis wawancara dalam penelitian ini adalah semi tersruktur, yakni tidak tergantung dengan pedoman wawancara, tetapi berkembang sesuai dengan konteks yang dibicarakan. Selain itu, peneliti melakukan wawancara informal dengan informan untuk mendapatkan data yang lebih mendalam. Wawancara ini apabila perlu juga dilakukan dengan siswa, guru kelas lain, kepala maupun pengawas sekolah untuk mendapatkan data yang lebih valid. Selanjutnya, teknik dokumentasi digunakan untuk menemukan fakta- fakta terkait dengan kegiatan perencanaan, pelaksanaan, dan evaluasi dalam penerapan pendekatan scientific. Data yang didokumentasikan meliputi: (1) analisis KD, (2) analisis Indikator, (3) Analisis tujuan pembelajaran, (4) analisis materi, dan (5) analisis evaluasi sesuai dengan pendekatan scientific. Selain itu, dokumentasi juga digunakan pada saat proses pengembangan desain pembelajaran.

Teknik analisis data yang digunakan adalah reduksi data, penyajian data, dan verifikasi. Teknik reduksi yang dilakukan ialah pemilahan hasil obseravsi dan hasil wawancara untuk digunakan dalam penyajian data. Selanjutnya data dikelompokkan dengan menggunakan tabel, dipisahkan antara perencanaan, pelaksanaan dan evaluasi penerapan pendekatan scientific, lalu dikelompokkan lagi dengan metode abjad, juga dengan pengelompokkan per sub bab yang ditanyakan atau hasil observasi yang sama. Teknik analisis berikutnya adalah penyajian data. Hal ini untuk memudahkan dalam membaca data yang sudah dikumpulkan. Data disajikan dalam bentuk tabel hasil observasi dan wawancara, serta disajikan gambar hasil dokumentasi pelaksanaan pembelajaran yang dilakukan di selama penelitian. Terakhir yakni menggunakan teknik verifikasi. Langkah yang dilakukan ialah mengecek kesesuian data hasil observasi dengan wawancara, sehingga pelaksanaan hingga akhir penelitian menemukan suatu kesimpulan yang kredibel.

\section{HASIL}

Berdarkan hasil analisis data diperoleh hasil penelitian ialah sebagai berikut: (1) pada perencanaan pembelajaran, RPP dibuat oleh guru saat kegiatan GUGUS selama 1 (satu) semester sekali, (2) pada pelaksanaan, Guru mengalami kekurangan alokasi waktu pada materi yang menggunakan media video, banyaknya penilaian yang harus dilakukan sehingga guru mengaku 
kekurangan waktu untuk melakukan penilaian apabila dilaksanakan dalam proses pembelajaran. Pendekatan Scientific dilakukan sesuai dengan RPP, (3) pada evaluai, beliau sering melakukan penginputan setelah pembelajaran, sehingga peneliti harus meminta hasil penilaian terlebih dahulu kepada guru, terakhir (4) pada proses Wawancara dan angket kepada peserta didik dilakukan saat jam istirahat, sehingga kurang efektif karena peserta didik sering bercanda dengan temannya. Proses wawancara dengan guru dilakukan dengan tergesa-gesa mengingat kesibukan profesi maupun kesibukan pribadi setelah pembelajaran selesai.

\section{PEMBAHASAN}

\section{Perencanaan Pembelajaran}

Hasil penelitian menemukan kegiatan perencanaan pembelajaran diawali dengan pengkajian terhadap silabus dengan mencermati KI dan KD. Selanjutnya pengkajian terhadap buku guru dan peserta didik. Hal yang ditemukan ialah terdapat perbedaan antara KI dan KD di silabus dengan buku panduan, sehingga guru harus memilah KD dan menyesuaikan materinya. Relevansi yang dimaksudkan yakni materi yang akan pokok yang akan disampaikan oleh guru harus memiliki kesesuaian dengan $\mathrm{KI}$ dan $\mathrm{KD}$ yang ada dalam silabus.

Hal ini memang seringkali menjadi masalah, hampir setiap tahunnya selalu ada inovasi terhadap KI dan KD yang ada, sementara buku panduan belajar masih belum terbaharui sesuai KI dan KD yang baru sehingga guru pun harus melaksanakan pengkajian KI dan KD serta buku panduan belajar untuk merencanakan sebuah pembelajaran. KI dan KD yang berubah setiap tahunnya tentunya dimaksudkan untuk memperbaiki mutu dan kualitas pembelajaran sesuai dengan perkembangan dan tuntutan zaman yang menunut manusia untuk terus aktif dan inovatif, sehingga kurikulum pun berkembang sedemikian rupa. Pada dasarnya para ilmuan dalam menerapkan metode ilmiah tetap menganut konsep dasarnya. Konsep yang dimaksud yaitu teknik logis, teknik eksperimental, prinsip-prinsip, standar evaluasi, dan standar etika. Penggunaan konsep ini sebenarnya proses pembelajaran lebih mudah diperbaiki oleh guru maupun pengembang kurikulum.

Dalam perencanaan pembelajaran ditemukan pula bahwa dalam menyusun RPP (Rencana Pelaksanaan Pembelajaran) acuannya yakni buku guru, dan menggunakan pendekatan scientific dalam mengembangkan langkah-langkahnya. RPP disusun bersama dengan kelompok guru per gugus sekolah, sehingga guru tidak menyusun setiap hari per pertemuan. Namaun masih dilakukan pengembangan RPP sendiri agar sesuai dengan kondisi sekolah. Adapun komponen RPP yang dibuat oleh guru antara lain: (1) kegiatan pendahuluan yang meliputi, identitas sekolah, tema/ subtema/ pembelajaran, KI, KD dan indikator, kelas/semester, alokasi waktu dan materi pembelajaran, (2) kegiatan inti, (3) kegiatan penutup telah melibatkan pendekatan scientific sesuai dengan buku guru. Berdasarkan penemuan di atas dapat ditarik sebuah kesimpulan yaitu kegiatan yang dilakukan oleh guru dalam perencanaan pembelajaran yakni mengkaji silabus, mengkaji buku guru dan buku peserta didik, serta menyusun RPP telah sesuai dengan yang telah ditetapkan oleh Kemendikbud.

\section{Pelaksanaan Pembelajaran}

Guru mengalami kekurangan alokasi waktu pada materi yang menggunakan media video bahkan materi terdakang tidak selesai karena kegiatan di luar sekolah. Perencanaan waktu adalah suatu hal yang penting dalam proses pembelajaran. Hal tersebut akan berkaitan dengan berhasilnya peserta didik dalam memahami materi. Senada dengan yang disampaikan oleh Hosnan (2014:26) bahwa menjadi pendidikan bukan hanya pandai mengajar namun juga harus bisa mengelola alokasi waktu dengan efektif. Jumlah tatap muka atau jam pelajaran dalam satu materi harus diperhatikan dengan seksama. Selain waktu dan materi yang diperkirakan harus efisien ialah strategi, sehingga guru tidak mengejar target pelajaran dengan tergesa-gesa. Peserta didik juga maksimal menerima materi serta target pemahaman tercapai.

Dalam pelaksanan pembelajaran guru sudah melaksanakan proses belajar mengajar dari kegiatan pendahuluan, inti, dan penutup. Pelaksanaan tersebut sudah menggunakan pendekatan scientific. Berdasarkan hasil observasi kegiatan pendahuluan yang dilakukan oleh guru antara lain: (1) mengondisikan peserta didik untuk siap belajar, suasananya yaitu membuka pelajaran dengan salam dan melakukan presensi untuk menanyakan kabar (2) mendiskusikan kompetensi yang sudah dan akan dipelajari, (3) menyampaikan garis besar materi dan manfaatnya dalam kehidupan sehari- hari, (4) menginformasikan teknik penilaian yang akan digunakan, meskipun dalam kegiatan ini jarang disampaikan oleh guru. Ranah penilaian pengetahuan dan keterampilan hanya sesekali disampaikan kepada peserta didik. Berdasarkan temuan peneliti, penilaian sikap dilakukan oleh beliau dengan cara mengingatkan agar peserta didik berdo'a dengan khusuk. Penilaian keterampilan disampaikan oleh beliau pada waktu peserta didik membuat kerajinan dari biji-bijian (kolase) dengan hasil akhir ditempel pada majalah dinding di tembok kelas. Berdasarkan hasil observasi Guru tidak menyampaikan teknik penilaian dan lingkup sebanyak 3 kali. Kegiatan pendahuluan oleh guru dapat disimpulkan sesuai lampiran Permendikbud Republik Indonesia Nomor 103 Tahun 2014, meskipun beberapa kali tidak melalukan kegiatan pendahuluan dengan tepat.

Pembelajaran setelah pendahuluan adalah kegiatan inti. Cirinya adalah adanya 5M (Mengamati, menanya mengumpulkan informasi, mengasosiasi, mengomunikasikan). Berdasarkan hasil observasi, secara garis besar guru melakukan kegiatan mengamati pada setiap pertemuan. Hasil angket dan wawancara peserta didik menyatakan bahwa guru melakukan kegiatan mengamati. Perlu diperhatikan di kegiatan mengamati yaitu memberikan media yang bervariasi, agar peserta didik selalu antusias terhadap pelajaran. Setiap hari mereka sering mengamati gambar dalam buku peserta didik. Pada kegiatan lain 
guru meminta siswa untuk melakukan pengamatan tentang video cara membuat tempe. Selain penggunaan video dalam hal media, guru juga menyediakan gambar. Adapun hasil dari mengamati yakni peserta didik mampu mengidentifikasi masalah (Sufairoh, 2017).

Selanjutnya kegiatan menanya, hal yang ditemukan adalah terdapat peserta didik yang aktif bertanya, tetapi ada pula yang pasif. Mereka yang belum terbiasa bertanya akan diam karena tidak tahu harus bertanya apa atau bisa juga lebih ramai sendiri dan mengganggu temannya. Hal ini disebabkan guru memberikan pertanyaan yang umum. Pertanyaan individu dapat dilakukan apabila sudah terjadi ketidakefektifan di dalam kelas. Hal ini justru dapat menambah fokus peserta didik secara individu. Perkembangan kemampuan bertanya akan tumbuh seiring dengan besarnya keingin tahuan pada diri peserta didik. Sejalan dengan (Setiawan, 2017) dengan munculnya pertanyaan, akan menimbulkan interaksi, interaksi inilah yang nantinya akan membentuk sebuah kebiasaan yang baik. Hal ini tentu harus didukung dengan munculnya pertanyaan yang berkualitas dari peserta didik. Berikutnya adalah kegiatan mengumpukan informasi. Peserta didik diberikan kesempatan untuk mengumpulkan info tentang makanan kesukaan teman-temannya sebanyak 10 anak. Mereka mewawancarai narasumber yang merupakan teman sekelasnya untuk mengumpulkan data melalui angket tentang makanan kesukaan.

Kegiatan tersebut dilakukan pada jam pelajaran sampai jam istirahat sekolah. Kegiatan wawancara terhadap teman satu kelas merupakan suatu kegiatan yang sebenarnya sangat sederhana, tetapi memiliki manfaat yang baik. Manfaat tersebut yakni guru dapat menghindari metode diskusi yang sering kali memakan banyak waktu, tidak efektif, dan efisien. Dengan melakukan diskusi sebagai wujud dari kegiatan mengumpulkan informasi, peserta didik bisa mengembangkan kemampuan berkomunikasi. Kegiatan memang di dalam kelas, tetapi daya keingintahuan anak terhadap temannya sangat besar, mereka juga merasa memiliki tangggung jawab besar dalam menyekesaikan tugas tersebut. Berbeda dengan kegiatan mengumpulkan informasi di sub tema makanan sehat dan makanan tidak sehat. Peserta didik hanya diminta mengumpulkan informasi melalui buku peserta didik, sehingga pada kegiatan ini peserta didik cenderung tidak antusias. Setelah kegiatan mengumpulkan informasi adalah menalar/mengasosiasi. Peserta didik membuat simpulan berdasarkan pertanyaan. Berdasarkan hasil penelitian kegiatan menalar ini sudah sesuai. Berdasarkan hasil observasi guru melakukan kegiatan ini dengan cara induktif. Guru memberikan pertanyaan kemudian peserta didik bisa menjawab kemudian membuat kesimpulan. Namun kendala yang dihadapi berdasarkan penelitian ialah terdapat peserta didik yang tidak cepat dalam membuat kesimpulan. Hal ini dipicu oleh pertanyaan guru yang klasikal. Sehingga terdapat peserta didik yang merasa kurang diperhatikan. Kegiatan lain yang serupa, guru telah memberikan alternatif cukup menarik. Siswa lebih antusias dan bisa membuat menalar dengan baik. Pada kegiatan mengomunikasikan juga telah sesuai. Guru membantu peserta didik untuk menyampaikan cerita secara baik. Awalnya mereka harus menyampaikan hasil dari pengumpulan informasi, kemudian siswa diminta untuk bercerita secara spontan.

Kegiatan berikutnya adalah penutup. Berdasarkan hasil observasi, guru membingkan peserta didik untuk menyimpulkan pada akhir pembelajaran yang diawali dengan tanya jawab. Guru melakukan kegiatan tersebut setiap akhir pembelajaran selama observasi dilakukan. Menyimpulkan seperti ini merupakan penalaran induktif. Refleksi dilakukan setiap akhir pembelajaran, tetapi terkadang tidak terlaksana kegiatan refleksi apabila materi pada hari tersebut belum selesai dan harus dilanjutkan esok hari. Untuk mengantisipasi hal tersebut sebenarnya guru bisa mengisi kegiatan refleksi dengan cara menanyakan kepada peserta didik kesan apa yang diperoleh terhadap pelajaran hari tersebut. Sehingga kegiatan refleksi tetap terlaksana. Menurut (Rusman,2011) menyatakan bahwa refleksi adalah belajar mengenai hal baru atau fenomena baru secara mendalam dan rasional berpikir. Berlandaskan dengan pendapat Rusman, guru bisa juga memberikan alternatif kegiatan refleksi berupa menanyakan saran tentang hal yang baru saja dipelajari sekalipun materi pelajaran tersebut belum usai dan harus dilanjutkan pertemuan selanjutnya. Berdasarkan hasil observasi tentang umpan balik yang dilakukan selama proses pembelajaran, guru melakukan tanya jawab soal-soal tentang materi yang sudah dipelajari. Umpan balik penting dilakukan, walaupun terkadang tidak dapat dilakukan kalau waktu sudah habis.

Berdasarkan RPP kegiatan penilaian dilakukan pada saat penutup. Selama kegiatan penutup hal berikut yang dilaksanakan oleh guru: (1) melakukan penilaian baik dengan memberikan soal maupun dalam bentuk yang lain, (2) memasukkan nilai peserta didik selama proses pembelajaran, (3) memberikan kegiatan tindak lanjut sesuai dengan buku peserta didik berupa pemberian pekerjaan rumah (PR). Remedial juga dilakukan bagi mereka yang memiliki nilai di bawah KKM yakni 70. Remedial dilakukan pasca Ulangan Harian dan setelah pulang sekolah.Rencana pembelajaran pada pertemuan berikutnya juga disampaikan pada penutup kegiatan pembelajaran. Menurut (Sagala,2013) bahwa menyampaikan tujuan materi yang akan dipelajari pada awal pertemua dan akhir penting adanya, sehingga peserta didik tahu dan siap untuk belajar maupun mempelajari terlebih dahulu mengenai materi tersebut.

\section{Penilaian Pembelajaran}

Evaluasi dalam kurikulum 2013 menggunakan penilaian autentik. Guru mengaku kekurangan waktu untuk melakukan penilaian karena banyak yang harus dilakukan selama proses pembelajaran. Merujuk pada pernyataan (Hidayah, 2015) bahwa penilaian ini mencatat hasil apa adanya, tanpa suasana tertekan. Berdasarkan hasil observasi tentang penilaian selama proses pembelajaran, guru melakukan penilaian sikap, pengetahuan dan keterampilan. Proses penilaian yang dilakukan guru sesuai dengan buku guru yang digunakan sebagai acuan oleh beliau. Pengembangan instrumen juga dilakukan oleh guru apabila dirasa perlu dilakukan. Pengembangan instrumen terkadang perlu dilakukan apabila instrumen yang ada kurang sesuai dengan kondisi lapangan. Misalnya, perubahan instrumen kerapian menjadi teliti pada penilaian sikap. 
Penilaian pengetahuan terlihat dilakukan oleh guru hanya melalui satu cara yakni instrumen tes tertulis. Adapun pedoman penskoran untuk instrumen tes tertulis sesuai dengan RPP yang dibuat oleh beliau yakni dengan 2 rentangan YA dan TIDAK untuk daftar periksa laporan tulisan, serta 4 kriteria pada rubrik laporan. Adapun rentangan kriteria tersebut yakni 4: sangat baik, 3: baik, 2: cukup dan 1: berlatih lagi. Berikut alur menilai yang dilakukan guru: pencatatan hasil penilaian dilakukan oleh guru bersama dengan peserta didik. Proses pencatatan hasil penilaian dilakukan setelah pembahasan jawaban bersama. Pada proses pembahasan terjadi pertukaran jawaban antar teman sebangku untuk selanjutnya dilakukan penilaian. Guru mengarahkan peserta didik untuk menghitung skor akhir serta menjelaskan cara melakukan penilaian. Setelah diperoleh nilai masing-masing pekerjaan peserta didik, mereka mencatat skor pada kertas jawaban teman sebangku. Guru memanggil nama peserta didik untuk menyebutkan skor yang diperoleh berdasarkan nomor presensi yang kemudian dimasukkan ke daftar nilai. Penilaian dan pencatatan skor pernah dilakukan sendiri oleh guru, yakni pada saat peserta didik melakukan kelompok. Hal tersebut dilakukan oleh beliau mengingat alokasi waktu kurang, sehingga beliau menilai serta memasukkan skor akhir sendiri. Acuan kriteria rerata digunakan untuk menilai akhir sub tema dan tema.

Terakhir nilai pengetahuan bisa pula melalui penugasan. Guru dapat memberikan tugas kepada peserta didik berupa PR, baik berupa tugas individu maupun kelompok sesuai dengan karakteristik materi yang diajarkan pada hari tersebut. Merujuk pada temuan penelitian bahwa guru sering kali tidak memberikan penilaian pada PR yang diberikan. Hal ini dikaitkan dengan harus adanya kerjasama dengan orang tua di dalam buku siswa mupun guru. Di sinilah letak kesalahan yang dilakukan oleh guru. Jadi bisa ditarik kesimpulan bahwa, pemberian nilai pengetahuan banyak sekali pilihannya, guru tidak perlu merasa kesulitan untuk pemberian penilaian ini.

Pada penilaian keterampilan, beliau menggunakan penilaian kinerja dan proyek. Sejalan dengan (Daryanto,2014) bahwa pengambilan nilai ranah keterampilan dapat dilaksanakan melelui pekerjaan peserta didik berupa kinerja kelompok, portofolio maupun projek yang lain. Guru memberikan penilaian hampir pada setiap pertemuan. Dalam pelaksanaannya, instrumen penilaian yang digunakan sesuai dengan buku guru yakni daftar periksa sesuai dengan rubrik penilaian yang ada. Misalnya dalam membuat grafik ada dua kriteria. Dalam kriteria ini menggunakan dua kategori, yakni YA dan TIDAK serta kolom keterangan apabila ada catatan tertentu tentang peserta didik. Selain penilaian kinerja, beliau juga melakukan penilaian proyek. Penilaian yang dilakukan yakni pada pembuatan kolase dari biji-bijian. Dalam penilaian proyek, beliau memberikan arahan kepada peserta didik sebelum memulai membuat produk. Demonstrasi cara membuat kolase juga diperagakan supaya peserta didik tidak mengalami kesulitan. Pada saat peserta didik membuat kolase, beliau sesekali berkeliling untuk melihat proses pembuatan. Adapun kriteria penilaian yang digunakan beliau yakni: teknik menggambar bentuk, kolase, pengeleman, dan ketepatan waktu bekerja. Masing-masing kriteria ini beliau gunakan empat penilaian, yakni: nilai 4 bagus sekali, 3 bagus, 2 cukup dan 1 perlu berlatih lagi.

Dalam penelitian yang dilakukan guru telah membuat instrumen penilaian, artinya pentingnya insrumen dan rubrik penilaian telah dipahami. Teknik penilaian tidak dapat lepas dari instrumen dan aspek-aspek penilaian dalam kaitannya untuk memantau perkembangan keterampilan peserta didik sesuai dengan kompetensi yang harus dikuasai. Selama observasi dilakukan guru belum menggunakan penilaian portofolio dalam menilai kemampuan keterampilan. Perlu diketahui bahwa kemajuan hasil kerja peserta didik selama proses pembelajaran bisa dilihat melalui portofolio. Pada penilaian sikap yang dilakukan oleh guru selama pembelajaran ialah menggunakan skala dengan kriteria sikap. Kriteria tersebut meliputi, teliti, percaya diri, kerjasama serta menghargai. Adapun skor untuk masing-masing kriteria beliau menggunakan rentangan $1-4$. Skor 1 belum terlihat, 2 mulai terlihat, 3 mulai berkembang, dan 4 membudaya. Guru melakukan penilaian kompentensi inti 1 tentang taat beribadah, bersyukur, berdoa, toleransi, serta kekhusukan berdoa. Kompetensi inti 2 tentang rasa tanggung jawab, teliti, percaya diri, kerja sama, jujur, dan disiplin. Penilaian dilakukan pada saat peserta didik mengerjakan tugas. Kriteria modus dipakai untuk menilai sikap di akhir sub tema dan tema. Penilaian ini dilakukan guru pada pertemuan ke-3, 9, 15, dan 21 dengan cara melihat skor peserta didik yang paling sering muncul. Hal ini bertujuan untuk melihat atensi, keakuratan serta tanggung jawab peserta didik (Indriani, 2015). Berdasarkan hasil observasi ulangan harian dan ulangan akhir sub tema dan tema selalu diadakan oleh guru. Hal ini diperkuat dengan hasil wawancara sebagai berikut: bahwa guru melakukan ulangan harian, ulangan subtema dan akhir tema. Hasil angket yang diberikan kepada peserta didik juga menunjukkan bahwa peserta didik mendapatkan soal dan diberi tahukan nilai ulangannya. Berdasarkan hasil temuan ini, bahwasannya beliau sudah melakukan evaluasi terhadap peserta didik, baik sikap, pengetahuan maupun keterampilan.

Kendala yang dihadapi guru adalah pelaksanaan kegiatan dan penilaian pembelajaran. Menurut hasil pengamatan guru kurang dalam hal memvariasikan kegiatan pembelajaran menggunakan pendekatan saintifik. Guru sering melaksanakan kegiatan pembelajaran sama persis dengan buku peserta didik. Kurangnya variasi dalam kegiatan ini sering kali membuat peserta didik kurang antusias terhadap pelajaran yang disampaikan. Guru sebaiknya selalu menyiapkan kegaitan yang menarik agar menarik keaktifan peserta didik. Seiring dengan pendapat Hamrin \& Toth (2012: 37) bahwa pendidik juga memiliki tugas untuk memberikan inspirasi pada peserta didik agar tetap aktif dan mampu menghasilkan produk maupun pemikiran dalam pembelajaran. Langkah yang dilakukan guru terkait dengan hambatan yang dialami adalah dengan berdiskusi dengan guru lain untuk mencari alternatif penyelesaikan hambatan tersebut. 


\section{Kebermaknaan Pembelajaran}

Berdasarkan hasil temuan tentang kebermaknaan pembelajaran kepada peserta didik, ditemukan bahwa peserta didik tertarik dengan pembelajaran scientific. Sesuai dengan hasil angket kepada peserta didik yakni tertarik dengan pembelajaran. Contoh pada materi membuat tempe, guru memutarkan video tentang cara pembuatan tempe. Memang sekilas hanya video, tetapi dalam hal pembuatan tempe ini peserta didik menjadi tahu bahwa tempe adalah makanan yang aman dikonsumsi, tidak diproduksi dengan menggunakan zat-zat seperti junk food maupun makanan ringan yang dijual di kantin. Mereka juga dapat belajar dengan cara tidak terikat waktu dan tempat, karena kebermaknaan belajar yang didapat. Hal ini dapat menumbuhkan perasaan akan kebutuhan untuk menuntut ilmu dalam pendidikan karena belajar memiliki makna. Sejalan dengan hasil penelitian (Sa'adah \& Mawardi, 2019) bahwa kebermaknaan meningkat dengan penerapan pembelajaran tematik terpadu menggunakan pendekatan scientific.

Kebermaknaan dalam hal pembuatan tempe ini mampu diaplikasikan peserta didik melalui pembuatan klipping tentang proses pembuatan tempe, berdiskusi, dan presentasi di depan kelas. Hal ini jelas menunjukkan kegiatan nyata kehidupan seharihari yang mampu diaplikasikan dalam pembelajaran secara nyata maupun langsung. Pembelajaran dikatakan bermakna apabila fenomena baru dapat diasosiasikan ke dalam struktur pengetahuan seseorang. Sejalan dengan (Rahmah, 2018) pembelajaran terjadi apabila seseorang telah membaharui pengetahuan mereka dengan cara menggabungkan sejarah atau hal yang pernah dilakukan, serta informasi maupun kenyataan baru ke dalam pemikiran mereka. Begitu juga (Aisyah, Gipayana, \& W, 2016) untuk mencapai kebermaknaan belajar dapat dilakukan melalui penyusunan rancangan pembelajaran secara tematik dan menyeluruh pada awal, proses dan akhir pembelajaran.

\section{SIMPULAN}

Secara umum, dapat disimpulkan bahwa dalam pelaksanaan pembelajaran scientific mengalami permasalahan. Secara khusus permasalahan guru dalam pelaksanaan pembelajaran scientific, meliputi (1) perencanaa pembelajaran tematik terpadu yang dilaksanakan oleh guru didapatkan beberapa fakta, yaitu kesulitan dalam mengembangkan instrumen penilaian, solusi yang telah ditempuh adalah melakukan kajian bersama guru lain maupun kepala sekolah. Terkait dengan pengkajian silabus, buku guru, dan siswa serta RPP dengan menjabarkan langkah pendekatan scientific sudah sesuai dengan yang ditetapkan, (2) pelaksanaan pembelajaran tematik terpadu yang dilaksanakan diperoleh beberapa fakta, yaitu: guru kekurangan waktu apabila menggunakan media video. Hal ini dapat diatasi oleh guru dengan cara pemberian tugas untuk peserta didik bagi materi yang belum selesai serta pemampatan materi dipertemuan selanjutnya. Pada pelaksanaan pendekatan scientific sudah dilakukan dengan baik oleh beliau, (3) penilaian pembelajaran tematik terpadu yang dilaksanakan oleh guru diperoleh beberapa fakta, yaitu: pelaksanaan penilaian yang membutuhkan waktu lama, sehingga guru harus melakukan penilaian selesai pembelajaran bahkan hal ini diatasi oleh beliau dengan cara dilakukan penilaian teman sebangku.

Dari hasil simpulan di atas, saran yang dapat diberikan oleh peneliti ialah sebagai berikut. Pertama, kepala sekolah melakukan pemantauan dalam pelaksanaan dan penilaian pembelajaran. Kedua, guru hendaknya terus berusaha dan adaptasi dengan adanya kurikulum baru khususnya pendekatan scientific. Ketiga, dinas terkait hendaknya mengusahakan pelatihanpelatihan tentang pendekatan scientific agar guru di lingkungan tersebut paham baik dan maksimal dalam pelaksanaan kurikulum 2013.

\section{DAFTAR RUJUKAN}

Akbar, S. (2013). Instrumen Perangkat Pembelajaran. Bandung: PT Remaja Rosdakarya Offset.

Aisyah, D. W., Gipayana, M., \& W, E. T. D. R. W. (2016). Mengembangkan Kebermaknaan Belajar dengan Rancangan Pembelajaran Tematik Bercirikan Quantum Teaching. 1-8.

Daryanto. (2014). Pendekatan Pembelajaran Saintifik Kurikulum 2013. Yogyakarta: Gava Media.

Hamrin, M., \& Melanie Toth. (2012). Pembelajaran Aktif yang Menginspirasi:Buku Pegangan Lengkap untuk Masa Kini. (Alih Bahasa: Bethari Anissa Ismayasari). Jakarta: PT. Indeks.

Hidayah, N. (2015). Pembelajaran Tematik Integratif di Sekolah Dasar. Terampil Pendidikan dan Pembelajaran Dasar, 2(1), 34-49.

Hosnan, M. (2014). Pendekatan Saintifik dan Kontekstual dalam Pembelajaran Abad 21 Kunci Sukses Implementasi Kurikulum 2013. Jakarta: Ghalia Indonesia.

Indriani, F. (2015). Kompetensi Pedagogik Mahasiswa Dalam Mengelola Pembelajaran Tematik Integratif Kurikulum 2013 Pada. Junal Profesi Pendidikan Dasar, 2(2), 87-94.

Junaidi, \& Aprison, W. (2017). Pendekatan Saintifik: Melihat Arah Pembangunan Karakter dan Peradaban Bangsa Indonesia. Epistemé: Jurnal Pengembangan Ilmu Keislaman, 12(2), 507-532. https://doi.org/10.21274/epis.2017.12.2.507-532

Mukhlis, M. (2012). Pembelajaran Tematik. Fenomena, IV(20), 63-76. https://doi.org/10.1002/pro.215

Raharjo, H. P. (2014). Penerapan Pendekatan Saintifik dalam Membentuk Karakter Positif Anak. Journal of Physical Education, Health, and Sport, 1(1), 48-59.

Rahmah, N. (2018). Belajar Bermakna Ausubel. Al-Khwarizmi: Jurnal Pendidikan Matematika dan Ilmu Pengetahuan Alam, l(1), 43-48. https://doi.org/10.24256/jpmipa.v1i1.54 
Rusman. (2011). Model-Model Pembelajaran: Mengembangkan Profesionalisme Guru. Jakarta: PT. Raja Grafindo Persada. Sa'adah, M., \& Mawardi. (2019). Peningkatan Kebermaknaan dan Hasil Belajar Siswa melalui Desain Pembelajaran Tematik Terpadu Alternatif Berbasis Projek pada Siswa Kelas 5 A. Jurnal Riset Teknologi dan Inovasi Pendidikan, 2(1), 1-14. Sagala, S. (2013). Konsep dan Makna Pembelajaran. Bandung: Alfabeta.

Setiawan, D. (2017). Pendekatan Saintifik dan Penilaian Autentik untuk Meningkatkan Mutu Pembelajaran Agama Islam. AlASASIYYA: Journal of Basic Education, 01(02), 34-46.

Sufairoh. (2017). Pendekatan Saintifik \& Model Pembelajaran K-13. Bahastra, 37(1), 89.

https://doi.org/10.26555/bahastra.v37i1.5641 